\title{
Rural-Urban Migration in Nigeria, Implication on the Development of the Society: Anambra State as the Focus of the Study
}

\author{
Anselem C. Nweke (Ph,D) \\ Department of Public Administration \\ Chukwuemeka Odumegwu Ojukwu University \\ E-mail: nwekeanselem@yahoo.com
}

Received: May 9, 2019 Accepted: June 2, 2019 Online published: June 11, 2019

doi:10.5296/jpag.v9i2.14912ＵRL: https://doi.org/10.5296/jpag.v9i2.14912

\begin{abstract}
This paper examines the implication of rural- urban migration on Nigeria Society using Anambra state as focus of the study. Cities have been growing both through natural increase and through stampede from rural areas in Nigeria. People migrate to urban areas based on the prevailing conditions they fund themselves and the reasons for the migration vary from one individual to another depending on the situation that informs the decision to migrate. In most rural areas, the effect of rural-urban migration was a rapid deterioration of the rural economy leading to poverty and food scarcity. The cause of the phenomenon has been described as the push factors in the rural areas and the pull factors in the urban areas. The objective of this paper is to identify the implication of rural-urban migration on Nigeria society. It is a survey research. Thus, 1200 questionnaire were distributed among the selected local governments in Anambra State. The analysis was run using Runs test and mode analysis. The result of the analysis found the effect of people migrating from rural areas to urban centres on the society to include: increase in prostitution in the urban centres; increase in squalor settlement in the urban centres; and people are doing all sorts of odd jobs in order to survive in urban centres. The paper therefore recommends that the government should make and implement a policy on provision of functional social amenities such as electricity, pipe borne water etc. in the rural areas. Good schools and qualified teachers should be made available in the rural areas and establishment of industries in both rural and urban areas that will to an extent accommodate unemployed youths.
\end{abstract}

Keywords: migration, implication, society 


\section{Introduction}

The vital part which cities play in the lives of the citizenry coupled with the important and far reaching problem created by urbanization, lends heavy substance to the idea of setting up as a matter of the utmost urgency, a dynamic and effective administrative machinery to administer the various service programmes and thus alleviate the ever-increasing rang of problems of urban life (Nweke 2012).It is important to note that Nigeria cities have been growing both through natural increase and through stampede from rural areas. Mini (2001) argued that in most rural areas, the impact of rural-urban migration was a rapid deterioration of the rural economy leading to chronic poverty and food insecurity. These arise mainly due to excessive drain of youth from the rural populace thus leaving only the older and aged members to constitute the labour force of the rural area.

The cause of the phenomenon has been described as the push factors in the rural areas and the pull factors in the urban centres. The dimension of the forces produced by these factors in many Nigeria communities has made "push and pull" to become understatements which could be replaced by "propulsive" and "magnetic". Honestly, the rural areas are beset by propulsive forces which send the youths in particular running post haste to the cities which have the magnetic factors that engulf the rural areas in their irresistible field. This has a lot of implication on the society.

Migration to urban areas is placing increasing pressure on local government's ability to respond to social service needs of urban populations. On-going migration to urban areas is placing pressure on limited appropriate housing, resulting in increases in the numbers of urban residents now found to reside in informal housing. Informal settlements present a range of health and development challenges to governments, including access to water, sanitation, housing, and adequate health services, including HIV services (Ambert, 2006; Ambert, Jassey, \& Thomas, 2007; Thomas, 2006).

The Nigeria, urban centres or cities are springing up and people are migrating from the rural areas to urban areas. And they have different reasons for migrating from rural areas to urban centres; these reasons may include among others lack of employment opportunities, lack of infrastructural facilities, educational institution etc. According to Afolayan (1995), rural areas can be easily identified by various criteria, apart from population. Such criteria include the level of infrastructural development i.e. road networks, educational institutions, water supply, electricity, health facilities, communication, etc. Other criteria used include Occupation, Housing, Extent of community planning etc. Ezeah (2005) argued that rural areas refer to geographical areas that lie outside the densely built-up environment of towns, cities and the sub-urban villages and whose inhabitants are engaged primarily in agriculture as well as the most basic of rudimentary form of secondary and tertiary activities. Rural area, which is the opposite of an urban area, refers to the country side whose population engages mainly in primary production activities like agriculture, fishing, and rearing of livestock (Ele, 2006). In his own view Nyagba (2009) argued that about 90 percent of the rural labour workforce engages directly or indirectly in agriculture.

Usually, urban centres assume increasing significance with the increasing rate of nation's 
development, for it is in these centres that a nation's capability is largely demonstrated. The fact is that most of the countries of the developing world are just on the threshold of their industrial take-off, and the patent deduction based on the previous unfolding of events in the western world that urbanization and industrialization goes together, indicates the simple fact that continuing rapid urbanization is inevitable in developing countries.

In the words of Sorenson (2004) \& Madu (2006) rural-urban migration results from the search for perceived or real opportunities as a consequence of rural-urban inequality in wealth. This inequality and/or urban bias in development according to research findings over the years results from the overwhelming concentration of wealth, assets, purchasing capacity, economic activities, and variety of services in the urban centres as well as the continued neglect and degradation of rural environments or areas (Harris \& Todaro 1970).

Urban life, is generally characterized by many issues which include among others, anonymity of the individual, norm conflicts, rapid social change, increased mobility of the population and emphasize on materialism. Urban life, tends to encourage individualism and a sharp decline in intimate communication as everybody always concentrates on his or her business as a result of its heterogeneous nature.

A distinguish characteristics of the city is that it is thickly populated with most of the people living in rented accommodation, while many people in the city engage in or, look for wage employment, others resort to self employment, doing various odd jobs to survive.

The problem that stimulates this present research interest is rate at which our youths (young boys and girls) are moving from rural areas to urban centres is very alarming. Also, the employment opportunities in the urban centres cannot accommodate exodus of people from rural areas.

Following this therefore, it has implication on Nigerian society. Agriculture has been neglected by our youths, thus unemployment and social vices are on increase (Abada 2001). This calls for deep inquiry to unravel the causes, true implication and solution to the rural-urban migration. The objective of this paper is to examine the implication of rural-urban migration in Nigeria Society.

Scope: This research work focuses on implication of rural-urban migration in Nigeria society: Emphasis would be on the local government in Anambra State. The paper will concentrate on two Local Government from each senatorial zone. We have three senatorial zones in Anambra state. Therefore, we will select 1 urban local government and 1 rural local government from each senatorial zone for our analysis.

Table 1. Distribution of local government on senatorial zones

\begin{tabular}{l|l}
\hline Senatorial Zones & Local Government Selected \\
\hline Anambra Central & Awka South and Awka North \\
\hline Anambra South & Nnewi North and Orumba North \\
\hline Anambra North & Onitsha North and Ayamelum \\
\hline
\end{tabular}

Source: field work 2017. 


\section{Research Methodology}

This study examines issues of drive, implication and solution to the problem of rural-urban migration in Nigeria. In view of the emerging nature of this research work, the survey research design was used.

This study explores both the primary and secondary sources of data collection. The primary data sources were collected through interview and questionnaire.

A total of 1,200 respondents were selected for both oral interview and questionnaire administration in six (6) delineated local government from three senatorial zones in Anambra state and 200 respondents for each local government.

\section{Data Presentation and Analysis}

An analysis was run using runs test and mode analysis to assess the effect of the rural-urban migration on social development of Nigeria (proxy by Anambra state, using six Local Government Areas namely; Awka South, Awka North; Nnewi North; Orumba North, Onitsha North and Ayamelum respectively). A total of 1,200 questionnaires were distributed to the respondents in the six LGA's of the states.

\section{Presentation of Questionnaire Response Data}

The questionnaire distributed was structured in a five point Likert scale questionnaire; a five-point module was chosen in a bid to achieve symmetry in-between the responses and as well to achieve an equidistant measure between the points. The coding for the responses was done as follows;

Strongly Agreed = 5, Agreed = 4, Neutral = 3, Disagreed = 2, Strongly Disagreed $=1$

Thus, the above coding was done in a regressive manner from 5-1, the further out the response from 5 closing on 1 indicates the more negative the response is, while the closer the response is to 5 , the more positive the response is.

Table 2. Presentation of Questionnaire Response Data

\begin{tabular}{l|l|l|l|l|l|l|l}
\hline & $\begin{array}{l}\text { AWKA } \\
\text { SOUTH }\end{array}$ & $\begin{array}{l}\text { AWKA } \\
\text { NORTH }\end{array}$ & $\begin{array}{l}\text { NNEWI } \\
\text { NORTH }\end{array}$ & $\begin{array}{l}\text { ORUMBA } \\
\text { NORTH }\end{array}$ & $\begin{array}{l}\text { ONITSHA } \\
\text { NORTH }\end{array}$ & AYAMELUM & TOTAL \\
\hline VALID & 152 & 149 & 161 & 138 & 157 & 143 & 900 \\
\hline INVALID & 37 & 22 & 23 & 57 & 39 & 39 & 217 \\
\hline $\begin{array}{l}\text { NOT } \\
\text { RETURNED }\end{array}$ & 11 & 29 & 16 & 5 & 4 & 18 & 83 \\
\hline TOTAL & 200 & 200 & 200 & 200 & 200 & 200 & 1200 \\
\hline
\end{tabular}

Source: field work 2017

The questions extracted from the questionnaire and used for our analysis are presented below; 
Table 3. The effect of people migrating from rural areas to urban centre's on the society

\begin{tabular}{|c|c|c|c|c|c|c|c|c|c|}
\hline $\mathrm{S} / \mathrm{n}$ & Question & SA & A & $\mathrm{N}$ & $\mathrm{D}$ & SD & t-value & $\begin{array}{l}\mathrm{P} \\
\text {-value }\end{array}$ & Decision \\
\hline 12 & $\begin{array}{l}\text { It leads to } \\
\text { increase in } \\
\text { prostitution in the } \\
\text { urban centres }\end{array}$ & $\begin{array}{r}515 \\
(42.9 \%) \\
\end{array}$ & $\begin{array}{r}314 \\
(26.2 \%) \\
\end{array}$ & $\begin{array}{r}114 \\
(9.5 \%) \\
\end{array}$ & $\begin{array}{r}200 \\
(16.7 \%) \\
\end{array}$ & $\begin{array}{r}57 \\
(4.8 \%) \\
\end{array}$ & -4.430 & 0.011 & significant \\
\hline 13 & $\begin{array}{l}\text { Increase in } \\
\text { squalor settlement } \\
\text { in the urban } \\
\text { centres }\end{array}$ & $\begin{array}{r}257 \\
(21.4 \%) \\
\end{array}$ & $\begin{array}{r}714 \\
(59.5 \%) \\
\end{array}$ & $\begin{array}{r}114 \\
(9.5 \%) \\
\end{array}$ & $\begin{array}{r}86 \\
(7.2 \%) \\
\end{array}$ & $\begin{array}{r}29 \\
(2.4 \%) \\
\end{array}$ & -2.896 & 0.044 & significant \\
\hline 14 & $\begin{array}{l}\text { People are doing } \\
\text { all sorts of odd } \\
\text { jobs in order to } \\
\text { survive in urban } \\
\text { centres }\end{array}$ & $\begin{array}{r}600 \\
(0.50 \%) \\
\end{array}$ & $\begin{array}{r}571 \\
(47.6 \%) \\
\end{array}$ & $\begin{array}{r}0 \\
(0.0 \%) \\
\end{array}$ & $\begin{array}{r}29 \\
(2.4 \%) \\
\end{array}$ & $\begin{array}{r}0 \\
(0.0 \%) \\
\end{array}$ & -2.549 & 0.063 & significant \\
\hline 15 & $\begin{array}{l}\text { Increase in } \\
\text { criminal activities } \\
\text { in urban centres }\end{array}$ & $\begin{array}{r}715 \\
(59.6 \%)\end{array}$ & $\begin{array}{r}371 \\
(30.9 \%)\end{array}$ & $\begin{array}{r}57 \\
(4.8 \%)\end{array}$ & $\begin{array}{r}29 \\
(2.4 \%)\end{array}$ & $\begin{array}{r}28 \\
(2.3 \%)\end{array}$ & -2.662 & 0.056 & $\begin{array}{r}\text { Not } \\
\text { significant }\end{array}$ \\
\hline
\end{tabular}

Source: field work 2017.

The result of the analysis presented found the effect of people migrating from rural areas to urban centres on the society to include: increase in prostitution in the urban centres; increase in squalor settlement in the urban centres; and people are doing all sorts of odd jobs in order to survive in urban centres. This is because responses on the corresponding questions were found to be significant at $95 \%$ confidence level.

Table 4. The Runs Test for Question No. 15

\begin{tabular}{|c|c|c|c|c|c|c|}
\hline & $\mid \begin{array}{lr}\text { RURAL-UBRA } \\
\text { N } & \text { MIGRATION } \\
\text { LEADS } & \text { TO } \\
\text { INCREASE } & \text { IN } \\
\text { CRIME RATE } \\
\text { (AWKA } \\
\text { SOUTH) }\end{array}$ & $\mid \begin{array}{lr}\text { RURAL-UBRA } \\
\text { N } & \text { MIGRATION } \\
\text { LEADS } & \text { TO } \\
\text { INCREASE } & \text { IN } \\
\text { CRIME RATE } \\
\text { (AWKA } & \\
\text { NORTH) } & \end{array}$ & $\mid \begin{array}{lr}\text { RURAL-UBRA } \\
\text { N } & \text { MIGRATION } \\
\text { LEADS } & \text { TO } \\
\text { INCREASE } & \text { IN } \\
\text { CRIME RATE } \\
\text { (NNEWI } \\
\text { NORTH) }\end{array}$ & $\begin{array}{l}\text { RURAL-UBRA } \\
\mathrm{N} \\
\text { MIGRATION } \\
\text { LEADS TO } \\
\text { INCREASE IN } \\
\text { CRIME RATE } \\
\text { (ORUMBA } \\
\text { NORTH) } \\
\end{array}$ & \begin{tabular}{lr}
\multicolumn{2}{l|}{ RURAL-UBRA } \\
N & MIGRATION \\
LEADS & TO \\
INCREASE & IN \\
CRIME RATE \\
(ONITHSA \\
NORTH)
\end{tabular} & $\begin{array}{l}\text { RURAL-UBRA } \\
\mathrm{N} \\
\text { MIGRATION } \\
\text { LEADS TO } \\
\text { INCREASE IN } \\
\text { CRIME RATE } \\
\text { (AYAMELUM) }\end{array}$ \\
\hline Test Value $^{\mathrm{a}}$ & 2.0000 & 2.0000 & 2.0000 & 2.0000 & 2.0000 & 2.0000 \\
\hline Total Cases & 46 & 43 & 40 & 38 & 41 & 44 \\
\hline Number of Runs & 15 & 12 & 10 & 12 & 13 & 12 \\
\hline $\mathrm{Z}$ & -2.527 & -3.070 & -3.334 & -2.425 & -2.228 & -2.334 \\
\hline $\begin{array}{ll}\text { Asymp. } & \text { Sig. } \\
(2 \text {-tailed) } & \\
\end{array}$ & .012 & .002 & .001 & .015 & .026 & .010 \\
\hline
\end{tabular}




\section{I Macrothink}

Journal of Public Administration and Governance

ISSN 2161-7104

2019, Vol. 9, No. 2

Source: field work 2017

From the results of the respondents in all six (6) local government areas, it can be deduced that the p- value (Asymp. Sig) is less than 5\% (0.05), hence the null hypothesis (people migrating from rural area to urban area has no effect on the society) reject and thus accepting that the responses are random.

Table 5. Response to Question No. 15

\begin{tabular}{l|l|l|l|l|l|l}
\hline \multicolumn{2}{l}{ Q15: Rural-Urban migration leads to increase in crime rate in urban areas } \\
\hline & AWKA & AWKA & NNEWI & ORUMBA & ONITSHA & \\
& SOUTH & NORTH & NORTH & NORTH & SOUTH & AYAMELUM \\
\hline SA & 72 & 87 & 95 & 78 & 70 & 62 \\
\hline A & 62 & 35 & 28 & 27 & 52 & 31 \\
\hline N & 5 & 8 & 2 & 0 & 5 & 0 \\
\hline D & 13 & 10 & 16 & 2 & 3 & 28 \\
\hline SD & 0 & 6 & 15 & 11 & 5 & 19 \\
\hline TOTAL & 152 & 146 & 156 & 118 & 135 & 140 \\
\hline
\end{tabular}

Source: field work 2017

$\mathrm{S} . \mathrm{A}=$ STRONGLY AGREED, $\mathrm{A}=$ AGREED, $\mathrm{N}=$ NEUTRAL, $\mathrm{D}=$ DISAGREED, $\mathrm{S} . \mathrm{D}=$ STRONGLY DISAGREED

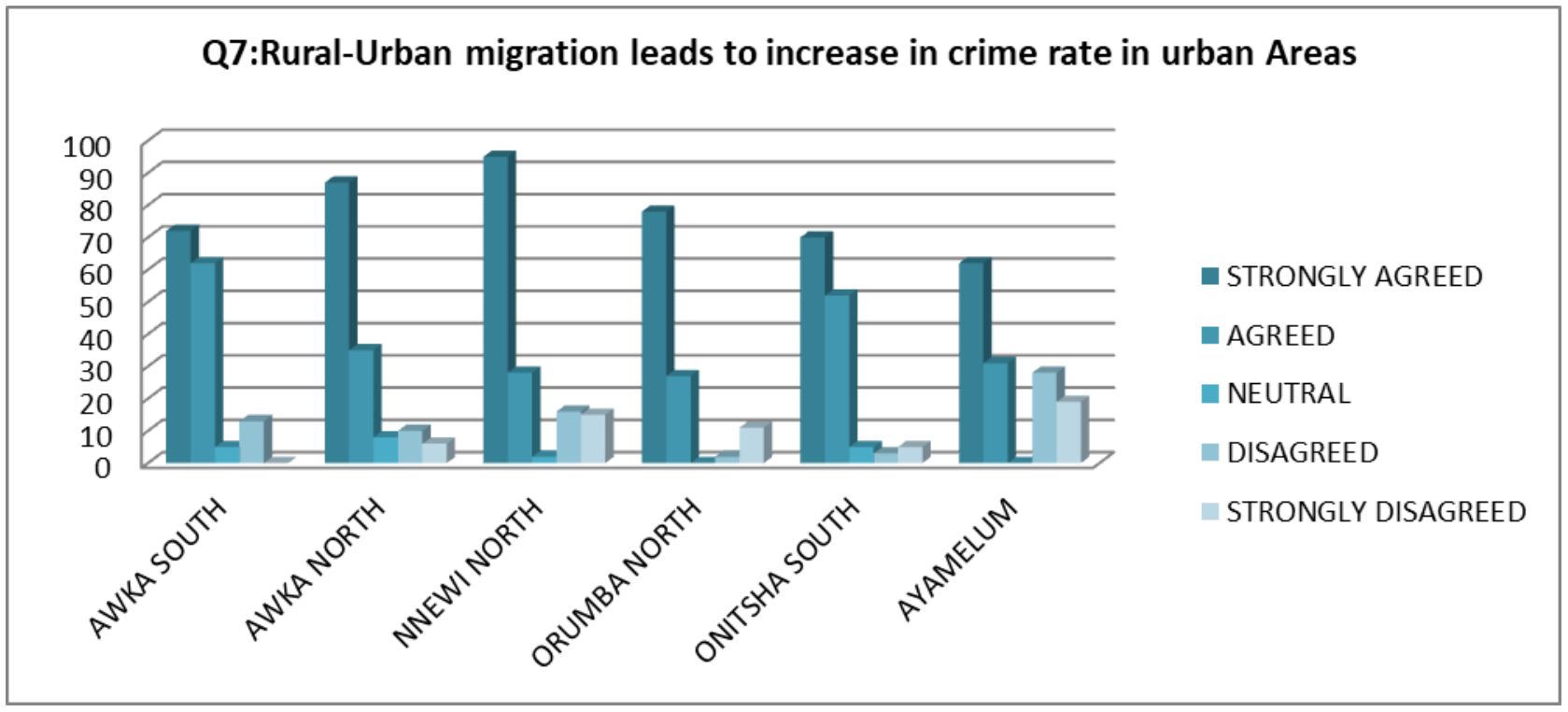

Figure 1. Mode Analysis of Question No. 15

From the above diagram, it can be discovered as well that the respondents from the selected local government areas jointly agree that rural-urban migration leads to an increase in crime rate in the urban areas.

\section{Conclusion}

In the context of this research, from the analysis conducted through primary data collection, graphical presentations and the runs test for randomness the research work has the following findings: rural-urban migration has led to an increase in crime rate in the urban areas; 
rural-urban migration has negative societal impact as the attention of government is drawn to development of urban areas, thus neglecting the rural areas. Rural-urban migration leads to increase in prostitution in the urban centre's; increase in squalor settlement in the urban centre's; and people are doing all sorts of odd jobs in order to survive in urban centre's. Also it deters development as it draws attention away from rural areas thus stunting its development.

\section{Recommendation}

Based on the findings, the paper has the following recommendations

1. Infrastructure: The government should make and implement a policy on provision of infrastructural facilities such as electricity, pipe borne water, health faculties etc. in the rural areas. This if provide will make these services readily available in the rural areas and reduce the rate at which these services are been sorted for in the urban areas

2. Education Policy: Good schools and qualified teachers should be made available in the rural areas, with adequate teaching and learning materials. Also the sitting of higher institution such as universities, polytechnics and colleges education in the rural area will to a great extent reduce rural- urban migration.

Investment: Establishment of industries in both rural and urban areas that will to a large extent accommodates unemployed youths. This will help in reducing crime and social vices

3. Adequate housing and sewage disposal mechanism should be provided by the government.

\section{References}

Abada, J. M. (2001) Urbanization in Nigeria: Trends, Causes and consequences, in Ezeani E.O \& Elekwa N.N (eds) Issues in Urbanization and Urban Administration in Nigeria. Enugu: Jamoe Enterprises

Afolayan, S. O. (1995). Community Mobilization for Rural Development in Bangladesh: Lessons for Nigeria. Ilorin: Agricultural and Rural Management Training Institute, ARMTI

Ambert, C. (2006) An HIV and Aids lens for informal settlement policy and practice in South Africa. In M. Huchzermeyer, \& A. Karam (Eds.), Informal Settlements -a perpetual challenge?Cape Town: UCT Press.

Ambert, C., Jassey, K., \& Thomas, E. (2007). HIV, AIDS and urban development issues in sub-Saharan Africa. Beyond sex and medicines: Why getting the basics right is part of the response! Stockholm.

Ele, C. (2006) Evangelization through Rural Development. Nsukka: Great AP Publishers Ltd. Enugu State (2009) Medium Term Implementation Plan-Enugu State Vision 2020-(2010-2013). Enugu State Government Publication. 


\section{Macrothink}

Journal of Public Administration and Governance ISSN 2161-7104 2019, Vol. 9, No. 2

Ezeah, P. (2005) Rural Sociology and Rural Development with Focus on Nigeria. Enugu: John Jacob Classic Publishers.

Harris, J. R., \& Todaro, M. P. (1970) Migration, unemployment and development: a two-sector analysis," The American Economic Review, 60(1), View at Google Scholar.

Madu, I. A. (2006) Spatial inequality in Nigeria: the imperative of geographic perspectives in the development process," Journal of Social and Economic Development, 8(2).

Mini, S. E. (2001). The impact of Rural-Urban Migration on Rural Economy in Rural Village. Available at www.geofileonline.com

Nweke, A. C. (2012). Understanding Urban Administration and management in Nigeria. Awka: Unuique Press.

Nyagba, S. (2009) “Review of Nigeria's Rural Development Policy for sustainable Development” paper presented at Business Round Table at Abuja, 9-11 July.

Sorenson, N. N. (2004). The development dimension of migrant remittances: toward a gendered typology," in Proceedings of the International Forum on Remittances, Washington, DC, USA.

Thomas, E. (2006). The Local Government Challenge of Healthy Development In Informal Settlements Especially in a Time of HIV/Aids. In M. Huchzermeyer, \& A. Karam (Eds.), Informal settlements -A perpetual challenge? Cape Town: UCT Press.

\section{Copyright Disclaimer}

Copyright for this article is retained by the author(s), with first publication rights granted to the journal.

This is an open-access article distributed under the terms and conditions of the Creative Commons Attribution license (http://creativecommons.org/licenses/by/4.0/). 